\title{
MULTIDRUG-RESISTANT TUBERCULOSIS AMONG MALE INMATES IN RIO DE JANEIRO, BRAZIL
}

\author{
Maria Cristina da Silva Lourenço ${ }^{1}$, Marlei Gomes da Silva ${ }^{2}$ and Leila de Souza Fonseca ${ }^{2 *}$ \\ ${ }^{1}$ Hospital Evandro Chagas, Fiocruz, Rio de Janeiro, RJ, Brasil, ${ }^{2}$ Departamento de Microbiologia Médica, Instituto de \\ Microbiologia Professor Paulo de Góes, Rio de Janeiro, RJ, Brasil \\ Submitted: March 08, 1999; Approved: February 17, 2000
}

\begin{abstract}
Susceptibility tests to six anti-tuberculosis drugs were performed on fifty-eight $M$. tuberculosis isolates obtained from tuberculous inmates in the Male Penal Sanatorium, Rio de Janeiro, Brazil. The rate of resistant tuberculosis was higher than that observed in the community. The overall resistance rate was $17.2 \%$ and $3.4 \%$ of the isolates were multi-drug resistant.
\end{abstract}

Key words: multi-drug resistance, M. tuberculosis, prisons

The emergence of multidrug-resistant tuberculosis (MDRTB) is one of the major threats to the control and prevention of tuberculosis (TB) in the world. (14). MDR-TB is extremely difficult and expensive to treat and to cure $(4,9)$.

The prison population is considered to be at particularly high risk of MDR-TB because of overcrowding, poor health, high prevalence of risk groups, late diagnosis and incomplete treatment. In Brazil, the last nationwide survey on drug resistance of isolates from 2,888 patients (1995-1996) showed a prevalence of $1.3 \%$ MDR-TB in the general community (13). However no information is available about the prevalence of resistant tuberculosis in incarcerated population.

In the present paper we report the prevalence of MDR-TB in the Male Penal Sanatorium, a center for tuberculous patients of the Prison System of the Rio de Janeiro State, during a 17month period (July/95 to November/96).

During the period of the study, sputum samples from 226 patients were submitted to mycobacteria isolation in the Bacteriological Laboratory of the Evandro Chagas Hospital, Fiocruz, RJ, Brazil. The sputum samples were decontaminated using Kubica's method, submitted to Ziehl-Neelsen staining and cultured in Loewenstein-Jensen medium for 8 weeks. The isolates were speciated by standard methods and tested for susceptibility to isoniazid $(0.2 \mu \mathrm{g} / \mathrm{ml})$, rifampin $(40 \mu \mathrm{g} / \mathrm{ml})$, pyrazinamide $(200 \mu \mathrm{g} / \mathrm{ml})$, ethambutol $(2 \mu \mathrm{g} / \mathrm{ml})$, streptomycin $(4 \mu \mathrm{g} / \mathrm{ml})$ and ethionamide $(20 \mu \mathrm{g} / \mathrm{ml})$ according to Canetti et al., (2). Multidrug resistance was defined as resistance to at least isoniazid and rifampin (13)

The data were collected and analyzed using a EPINFO (version 5 software). Proportional variables were compared and analyzed by univariate method (chi-square test, Fisher's exact test).

The mean age of the 226 male inmates included in this study was 29.8 years \pm 7.59 . M. tuberculosis was isolated from 111 patients $(49.1 \%)$. Fifty-eight isolates were tested for susceptibility to anti-TB agents. The remaining 53 positive cultures could not be tested because of the growing of less than 20 colonies/tube. No patient supplied more than one isolate.

Table 1 shows the results of the drug susceptibility tests. Resistance to one drug was detected in 6 strains $(10.3 \%)$. Eight strains were resistant to isoniazid $(13.8 \%)$, with or without association with other drug, while 5 were resistant to

\footnotetext{
*Corresponding author. Mailing address: Instituto de Microbiologia Prof. Paulo de Góes, Centro de Ciências da Saúde, Bloco I, Cidade Universitária, Ilha do Fundão, CEP 21941-590, Rio de Janeiro, RJ, Brasil, Fax: (+5521) 560-8344, E-mail: immmson@microbio.ufrj.br
} 
streptomycin $(8.6 \%)$. Resistance to at least one anti-TB drug was detected in 10 isolates, and the overall resistance was $17.2 \%$. Two strains (3.4\%) were multidrug resistant (MDR), i.e. resistant to isoniazid and rifampin with or without resistance to other antituberculous agents. Strains resistant to isoniazid and streptomycin were not considered MDR. Forty-eight isolates $(82.7 \%)$ were susceptible to all drugs. Mono-resistance to rifampin, pyrazinamide, ethambutol and ethionamide was not observed.

Table 1- Antituberculosis drug resistance among $M$. tuberculosis isolates obtained from 58 tuberculous male inmates in Rio de Janeiro, Brazil, 1995 $1996^{\mathrm{a}}$.

\begin{tabular}{lcc}
\hline Type of resistance & $\begin{array}{c}\text { Number of } \\
\text { resistant isolates }\end{array}$ & $\begin{array}{c}\text { Percent of } \\
\text { resistance }\end{array}$ \\
\hline Resistance to one drug & $6^{\mathrm{b}}$ & 10.3 \\
Resistance to INH plus SM & 2 & 3.4 \\
Multi-drug resistance & $2^{\mathrm{c}}$ & 3.4 \\
Total & 10 & 17.2 \\
\hline
\end{tabular}

a Drugs include isoniazid (INH), rifampin (RIF), pyrazinamide (PZA), ethambutol (EMB), streptomycin (SM) and ethionamide (ETH).

${ }^{\mathrm{b}}$ Two isolates resistant to SM and 4 to INH.

'One isolate resistant to INH, RIF and PZA and one resistant to INH, RIF, PZA, EMB, ETH and SM.

The emergence of strains of $M$. tuberculosis that are resistant to antimycobacterial agents, although not a new problem, has recently received increased attention largely due to the dramatic outbreaks of MDR-TB in HIV-infected patients in the United States $(3,6,8)$. However, resistance of M. tuberculosis to antimycobacterial agents is a worldwide problem in both immunocompetent and HIV-infected populations $(9,11)$. On the other hand, TB has long been recognized as a problem in prisons. In the USA, the incidence of TB among inmates is estimated to be 4 times the rate for the general population $(10,15)$. Little information is available about this problem in developing countries $(5,12)$. The present study represents the first attempt to describe drug-resistance patterns of tuberculosis in a correctional facility in Rio de Janeiro, Brazil.

In the last nationwide survey (1995-1996) the prevalence of combined (primary and acquired) resistance to any drug was $9.0 \%$ and the multi-drug resistance was $1.3 \%$ (13). In this study, the prevalence of $M$. tuberculosis isolates resistant to any drug $(17.2 \%)$ in the Penal Sanatorium was almost twice the overall resistance in the community, but was close to that found in a tertiary-care reference center for AIDS (13.4\%). No statistical difference was observed between the two populations $(\mathrm{p}=0.64)$. The same was observed on the prevalence of MRD-TB (7).

Resistance to streptomycin, detected as the most common in the former national survey, probably is a consequence of the wide use of streptomycin for treating tuberculosis in our country (1). In this study, the number of isoniazid-resistant isolates was higher than those resistant to streptomycin. Since streptomycin is no longer considered the first choice for tuberculosis treatment, resistance to streptomycin tends to decrease. The resistance pattern found in this study suggests the occurrence of new resistant strains in the population. In the last nationwide survey, a similar picture was observed. The frequency of isoniazidresistant isolates $(6.3 \%)$ was higher than the frequency of streptomycin-resistant isolates (3.8\%) (13).

Results of this study must be interpreted with caution due to the intrinsic design. In the absence of TB records, the distinction between primary and acquired resistance depends on the report of the patient. Due to the lack of reliable information on history and duration of previous treatment, new and relapse cases could not be characterized.

The correctional facilities have a number of predisposing factors that facilitate the development and spread of resistant $\mathrm{TB}$, including irregular treatment, poor patient compliance, overcrowding, high prevalence of risk groups as HIV-infected and drugs users, etc. Releases of tuberculous prisoners serve as a new source of transmission of resistant strains to the general community. National TB programs have to take into account the problem that currently exists in prisons. The frequency of $\mathrm{TB}$ in prisons, which is much higher than in the community, is underreported.

In conclusion, the level of resistance observed in our study suggest that all isolates of $M$. tuberculosis should be tested for drug susceptibility and that a surveillance system on drug resistance in prisons should be set up.

\section{RESUMO}

\section{Tuberculose multi-resistente entre pacientes do Sanatório Penal Masculino do Estado do Rio de Janeiro}

Testes de suscetibilidade a seis drogas anti-tuberculose foram realizados em 58 amostras de $M$. tuberculosis isoladas de pacientes do Sanatório Penal Masculino do Rio de Janeiro, Brasil. Foi observada uma alta taxa de resistência quando comparada com as taxas encontradas na comunidade. A resistência total (a qualquer droga) foi de 17,2\% e a multiresistência de $3,4 \%$.

Palavras-chave: tuberculose, multi-resistência, prisão.

\section{REFERENCES}

1. Barreto, A.M.W.; Martins, F.M. Estudo da resistência primária no Brasil no período de 1986 a 1988. Bol. CNCT, 2;21-25, 1988.

2. Canetti, G.; Rist, N.; Grosset, J. Mesure de la sensibilité du bacille tuberculeux aux drogues antibacillaires par la méthode des proportions. Méthodologie, critères de résistance, résultats, interprétation. Rev. Tuberculose Pneumol., 27: 217-272, 1963. 
3. Centers for Disease Control. Nosocomial transmission of multidrugresistant tuberculosis among HIV-infected persons - Florida and new York, 1988-1991. MMWR Morb. Mortal. Wkly. Rep., 40:585-591, 1991.

4. Centers for Disease Control and Prevention. Initial therapy for tuberculosis in the era of multidrug resistant: Recommendations of the Advisory Council for the Elimination of Tuberculosis. MMWR Morb. Mortal. Wkly. Rep., 42 (RR-7):1-8, 1993.

5. Coninx, R.; Pfyffer, G.E.; Mathieu, C.; Savina, D.; Debacker, M.; Jafarov, F.; Jabrailov, I.; Ismailov, A.; Mirzoev, F.; de Haller, R.; Portaels, F. Drug resistant tuberculosis in prisons in Azerbaijan. BMJ,316:1423-1425, 1998

6. Edlin, Br.; Tokars, J.I.; Grieco, M.H.; Crawford, J.T.; Williams, J.; Sordillo, E.M.; Ong, K.R.; Kilburn, J.O.; Dooley, S.W.; Castro, K.R.; Jarvis, W.R.; Holmberg, S.D. An outbreak of multidrug-resistant tuberculosis among hospitalized patients with the acquired immunodeficiency syndrome. $N$. Engl. J. Med., 326: 1514-1521, 1992.

7. Fandinho, F.C.O.; Kritski, A.L.; Hofer, C.; Conde Jr., H.; Ferreira, R.M.C.; Silva, M.G.; Fonseca, L.S. Drug Resistance Patterns among Hospitalized Tuberculous Patients in Rio de Janeiro, Brazil, 1993-1994. Mem. Inst. Oswaldo Cruz. 94:543-547, 1999.

8. Fischl, M.A.; Uttamchandani, R.B.; Daikos, G.L.; Poblete, R.B.; Moreno, J.N.; Reyes, R.R.; Boota, A.M.; Thompson, L.M.; Cleary, T.J.; Lai, S. An outbreak of tuberculosis caused by multiple-drug- resistant tubercle bacilli among patients with HIV infection. Ann. Intern. Med., 117: 177-183, 1992.
9. Goble, M.; Iseman, M.D.; Masen, L.A.; Waite, D.; Ackerson, L.; Horsburgh Jr. C.R. Treatment of 171 patients with pulmonary tuberculosis resistant to isoniazid and rifampin. N. Engl. J. Med., 328:527-532, 1993.

10. Hutton, M.D.; Cauthen, G.M.; Bloch, A.B. Tuberculosis in nursing homes and correctional facilities: results of a 29 state survey. Public. Health. Rep., 108:305-314, 1993.

11. Kochi, A.; Vareldzis, B.; Styblo, K. Multidrug-resistant tuberculosis and its control. Res. Microbiol., 144:104-110, 1993.

12. Niero R. Tuberculose pulmonar em uma prisão: estudos de alguns aspectos epidemiológicos como subsidio para seu contole. Tese. Escola de Saúde Pública da Universidade de São Paulo, 1991.

13. Pablos-Méndez, A.; Raviglione, M.C.; Laszlo, A.; Binkin, N.; Rieder, H.L.; Bustreo, F.; Cohn, D.L.; Lambregts-van Weezenbeek, C.S.B.; Kim, S.J.; Chaulet, P.; Nunn, P. Global surveillance for antituberculosis-drug resistance, 1994-1997. N. Engl. J. Med., 338:1641-1649, 1998.

14. Raviglione, M.C.; Snider, D.E.; Kochi, A. Global epidemiology of tuberculosis, morbidity and mortality of a worldwide epidemic. JAMA, 273:220-226, 1995.

15. Snider, D.E.; Hutton, M.D. Tuberculosis in correctional institutions. JAMA, 261:436-437, 1989. 